\title{
PENGARUH JIWA WIRAUSAHA DAN MANAJEMEN PEMASARAN TERHADAP KEBERHASILAN USAHA PADA AGROWISATA LEMBAH BAMBU KUNING
}

\author{
${ }^{1}$ Rosy Febriani Daud, ${ }^{2}$ Ibrahim Fikma Edrisy \\ ${ }^{1}$ Program studi Ilmu Komunikasi \\ ${ }^{2}$ Program studi Ilmu Hukum \\ Fakultas Hukum dan Ilmu Sosial, Universitas Muhammadiyah Kotabumi \\ Jalan Hasan Kepala Ratu No.1052 Sindang Sari Kotabumi Lampung Utara 34517 \\ Email: $\underline{\text { rosydaud@gmail.com }}$ \\ Submitted: 22 Desember 2021| Accepted: 30 Desember 2021 | Published: 31 Desember 2021 \\ Website: https://e-journal.umc.ac.id/index.php/jike/index \\ DOI: https://doi.org/10.32534/jike.v5i1.2504
}

\begin{abstract}
ABSTRAK
Perkembangan Usaha Mikro Kecil dan Menengah (UMKM) di Kabupaten Lampung Utara khususnya di Desa Abung Jayo Kecamatan Abung Selatan sangat minim dikarenakan jumlah tenaga kerja setiap tahunnya tidak ada peningkatan, jumlah pelanggan kurang meningkat dan jumlah penjualan pun kurang meningkat. Tujuan penelitian ini menganalisis pengaruh jiwa wirausaha dan manajemen pemasaran terhadap keberhasilan usaha para wirausaha di lingkungan Agrowisata Lembah Bambu Kuning Desa Abung Jaya Kabupaten Lampung Utara. Metode penelitian adalah eksplanasi (Explanatory Research), yaitu mencari hubungan dan pengaruh dari dua variabel yaitu antara variabel jiwa wirausaha dan variabel manajemen usaha dengan variabel keberhasilan usaha. Pendekatan yang digunakan penelitian adalah pendekatan kuantitatif yaitu data penelitian berupa angka-angka dan analisis menggunakan statistik. Hasil penelitian yang didapat adalah Hasil uji t, dengan taraf signifikansi $\alpha=0,05$, semua nilai Sig dari koefisien regresi lebih besar dari 0,05 , sehingga menunjukkan pengujian yang terdiri dari jiwa wirausaha dan manajemen pemasaran secara parsial berpengaruh negatif dan signifikan terhadap keberhasilan usaha para pelaku Usaha Mikro Kecil dan Menengah (UMKM) di Agrowisata Lembah Bambu Kuning Desa Abung Jaya Kabupaten Lampung Utara dengan demikian hipotesis pertama tidak terbukti. Selanjutnya dilihat dari hasil uji F diperoleh nilai sig sebesar 0,000. Dengan taraf signifikansi $\alpha=0,05$, ternyata nilai sig $>0,05$, sehingga menunjukkan pengujian yang signifikan. Ini berarti variabel jiwa wirausaha dan manajemen pemasaran secara simultan berpengaruh negatif dan signifikan terhadap keberhasilan usaha para pelaku Usaha Mikro Kecil dan Menengah (UMKM) di Agrowisata Lembah Bambu Kuning Desa Abung Jaya Kabupaten Lampung Utara dengan demikian hipotesis kedua yang diajukan tidak terbukti.
\end{abstract}

Kata Kunci: Kewirausahaan; Manajemen Pemasaran; Keberhasilan Usaha

\section{A. PENDAHULUAN}

Krisis ekonomi yang terjadi di Indonesia pada saat ini memiliki dampak negatif pada berbagai roda kehidupan terutama ekonomi. Kondisi perekonomian yang pada dasarnya belum kembali normal, sedikit banyak mempengaruhi iklim dunia usaha, baik usaha mikro, usaha skala kecil, 
menengah dan skala besar. Walaupun pengaruh krisis ekonomi usaha kecil dan menengah memiliki pengaruh yang tidak besar pada golongan usaha besar, tidak menutup kemungkinan dampaknya terhadap usaha kecil dan menengah cukup memiliki arti, yakni lemahnya daya beli masyarakat.Selain permasalahan krisis yang terjadi, persaingan perdagangan dengan negara lain yang cenderung makin ketat (kompetitif), tidak lagi memandang batas negara (globalisasi) mengharuskan dunia usaha dalam negeri meningkatkan kualitas di berbagai faktor usaha sehingga memiliki daya saing tinggi (marketable) di pasar dalam negeri maupun pasar luar negeri.

Melihat kondisi realitas yang dihadapi usaha kecil dan menengah (UKM) yang bersifat ekonomi kerakyatan, berada pada posisi yang kurang dari perhatian pemerintah. Padahal sebenarnya dari segi kuantitas, proporsi usaha kecil dan menengah (UKM) mencapai proporsi mayoritas lebih dari $90 \%$ pelaku ekonomi. Dengan melihat pengalaman, keberadaan usaha kecil dan menengah dapat diandalkan sebagai penggerak pertumbuhan dan pembangunan ekonomi, serta dapat bertahan dimasa sulit (krisis) yang sekarang tengah kita hadapi bersama. Keberadaan usaha kecil dan menengah (UKM) dapat memberikan kontribusi yang cukup besar terhadap kesempatan kerja dan pendapatan masyarakat.

Definisi UMKM menurut Kementrian Koperasi dan UMKM dalam Aufar (2014:8): Usaha Kecil (UK), termasuk usaha Mikro (UMI) adalah entitas usaha yang mempunyai kekayaan bersih paling banyak Rp. 200.000.000, tidak termasuk tanah dan bangunan tempat usaha dan memiliki penjualan tahunan paling banyak Rp. 1.000.000.000. Sementara itu, Usaha Menengah (UM) merupakan entitas usaha milik warga negara Indonesia yang memiliki kekayaan bersih lebih besar dari Rp. 200.000 .000 s.d. Rp. 10.000 .000 tidak termasuk tanah dan bangunan.Dengan melihat definisi menurut Kementrian Koperasi dan UMKM di atas dapat disimpulkan bahwa UMKM adalah usaha milik orang perorangan suatu badan usaha yang bukan merupakan anak atau cabang dari perusahaan lain dengan kriteria memiliki modal usaha yang memiliki batasan-batasan tertentu

Secara umum permasalahan kondisi usaha mikro, kecil dan menengah (UMKM) di Indonesia, dapat dikategorikan meliputi; permasalahan eksternal dan permasalahan internal. permasalahan eksternal berupa kebijakan pemerintah yang kurang berpihak, krisis yang berkepanjangan, dan persaingan dagang.Sedangkan permasalahan internal usaha kecil dan menengah yang ada pada umumnya UMKM memiliki keterbatasan, seperti penguasaan teknologi yang masih rendah, kekurangan modal usaha, akses pasar yang terbatas, dan keterbatasan manajerial usaha. Permasalahan-permasalahan tersebut semakin menambah kompleknya permasalahan, layaknya jaringan yang saling terkait (vicious circle) antara permasalahan yang satu dengan lainnya.

Kelompok usaha menengah dan kecil serta rumah tanggamempunyai potensi yang cukup besar dalam membantu mendinamisasi perekonomian masyarakat luas, mengingat usaha ini mempunyai efek pengganda (multiplier effect) langsung maupun tidak langsung yang relatif cukup tinggi terutama dilihat dari sifat, jenis dan sebaran kelompok usaha ini. Akan tetapi, meskipun usaha ini dominan dalam jumlah maupun penyerapan tenaga kerja, namun dari sisi output yang dihasilkan ternyata kontribusinya kecil.

Untuk mendorong dan menumbuhkembangkan perekonomian bangsa dengan melakukan pemberdayaan usaha mikro, kecil dan menengah (UMKM), tidak dapat dilepaskan dari faktor kewirausahaan, baik kewirausahaan sebagai ilmu maupun kewirausahaan sebagai profesi. Pelaku ekonomi yang bergerak pada skala usaha kecil dan menengah haruslah para pelaku yang memiliki jiwa wirausaha, memiliki kemampuan (dapat diperoleh dalam bangku pendidikan 
formal maupun pengalaman) sehingga dengan hal tersebut pelaku usaha mampu memanajemeni usahanya dengan baik dan keberhasilan yang diharapkan tercapai. Dari para wirausahawan yang tangguh diharapkan dapat memanfaatkan peluang usaha sehingga akan mendorong proses pergeseran skala usaha dari pengusaha kecil ke menengah, dari pengusaha menengah ke pengusaha besar dan pengusaha besar menjadi lebih besar. Sedangkan untuk kondisi usaha mikro, kecil dan menengah (UMKM) di Propinsi Lampung khususnya Kabupaten Lampung Utara tidak jauh berbeda dengan kondisi UKM secara nasional, hal ini dikarenakan kondisi dan permasalahan UMKM ini tidak terjadi secara parsial berdasarkan daerah tetapi terkait erat dengan kurang berdaya gunanya sektor ini secara hampir menyeluruh (nasional) yang disebabkan permasalahan eksternal dan internal dari UKM itu sendiri sebagaimana telah diterangkan sebelumnya.

Berdasarkan argumentasi diatas, kewirausahaan memiliki pandangan, pertama kewirausahaan muncul sebagai bakat, bawaan sejak lahir yang dipengaruhi oleh faktor turunan. Kedua, kewirausahaan dapat dipelajari baik itu dibangku pendidikan (secara formal) maupun dari proses pengalaman yang dialami baik oleh pribadi maupun orang lain (secara informal). Suatu usaha dapat dilakukan dengan sukses dan berhasil apabila ada bakat atau tertanam jiwa wirausaha dalam diri seseorang. Dalam buku Suparyanto (2012:24), bakat atau jiwa kewirausahaan bisa dimiliki seseorang sejak kelahirannya dan itu menjadi pembawaannya sejak lahir. Bakat atau jiwa kewirausahaan pun bisa dibentuk dengan cara belajar atau dari ilmu pendidikan dan pengalaman seseorang atau pengalaman pribadi. Berkaitan dengan bakat kewirausahaan itu baiknya ilmu kewirausahaan itu ajarkan dan dipraktikan mulai dari bangku pendidikan dasar sampai perguruan tinggi. Bakat atau Jiwa kewirausahaan merupakan faktor yang memotifasi seseorang untuk dapat melakukan suatu kegiatan berwirausaha, sehingga bakat atau jiwa kewirausahaan dapat dimaknai sebagai salah satu faktor pendorong perilaku seseorang. Dengan melihat faktir tersebut, setiap wirausaha yang sukses memiliki pola pikir atau ciri kepribadian sendiri atau kerap disebut dengan jiwa wirausaha.

Untuk menjadi wirausahawan yang berhasil, sejumlah tantangan baik internal maupun eksternal telah menghadang, tantangan internal berupa semangat atau etos wirausaha, keahlian di bidang manajemen, maupun pengembangan kepribadian wirausahawan dan modal. Sedangkan tantangan eksternal berupa iklim yang masih kurang kondusif bagi berkembangnya wirausahawan. Tidak hanya itu jumlah tenaga kerja UMKM setiap tahunnya tidak ada peningkatan, jumlah pelanggan yang kurang meningkat dan jumlah penjualan yang kurang meningkat. Para pelaku Usaha Mikro Kecil dan Menengah (UMKM) juga belum menerima pelatihan mengenai strategi dalam memasarkan produk dari instansi terkait. Manamejen pemasaran sangatlah penting untuk mengembangkan usaha dan untuk keberhasilan suatu usaha, terlebih lagi dengan kondisi pandemi Covid-19 seperti saat ini.Keberhasilan usaha menurut Suryana dalam Suarmawan (2015:4) adalah keberhasilan dari bisnisdalam mencapai tujuanya.

Berdasarkan latar belakang diatas penulis tertarik melakukan penelitian yang bertujuan menganalisis pengaruh jiwa wirausaha dan manajemen pemsaran terhadap keberhasilan usaha para wirausaha di lingkungan Agrowisata Lembah Bambu Kuning Desa Abung Jaya Kecamatan Abung Selatan Kabupaten Lampung Utara. Teori yang dipakai adalah teori Bauran Pemasaran (Marketing Mix). Rumusan masalah penelitian ini yaitu bagaimana pengaruh jiwa wirausaha dan manajemen pemasaran terhadap keberhasilan usaha dan seberapa kuat pengaruh jiwa wirausaha dan manajemen pemasaran terhadap keberhasilan usaha di sekitar agrowisata Lembah Bambu Kuning Desa Abung Jaya Kecamatan Abung Selatan Kabupaten Lampung Utara. 


\section{B. TINJAUAN PUSTAKA}

\section{Kewirausahaan}

Pada dasarnya secara substansial antara wiraswasta, wirausaha dan entrepreneurship tidak berbeda, hal demikian dapat dilihat pada definisi-definisi yang dikemukakan oleh beberapa pakar khususnya yang menggeluti bidang tersebut. Eddy Soeryanto Soegoto (2014:27) mengatakan "kewirausahaan adalah orang yang berjiwa kreatif, inovatif, mandiri, percaya diri, ulet dan tekun, rajin, disiplin, siap menghadapi resiko, jeli melihat dan meraih peluang, piawai mengelola sumber daya, dalam membangun, mengembangkan dan menjadikan usaha atau perusahaannya unggul." Menurut Hisrich-Peters (Suryana dan Bayu, 2013), "kewirausahaan adalah proses menciptakan sesuatu yang lain dengan menggunakan waktu dan kegiatan disertai modal dan risiko serta menerima balas jasa dan kepuasan serta kebebasan pribadi”. Beberapa pendapat tersebut, memiliki kesamaan inti antara definisi kewirausahaan yang satu dengan lainnya. Kewirausahaan merupakan proses penciptaan sesuatu yang baru dan berbeda dengan menggunakan waktu, modal, serta berani mengambil risiko untuk meningkatkan kesejahteraan individu.

\section{Jiwa Wirausaha}

Suryana (2014:10) mengatakan bahwa "Jiwa kewirausahaan ada pada setiap orang yang memiliki kemampuan kreatif dan inovatif, pada setiap orang yang meyukai perubahan, pembaruan, kemajuan, dan tantangan." Entrepreneurship mengandung makna wiraswasta atau wirausaha yaitu cabang ilmu ekonomi yang mengajarkan bagaimana kita bisa mandiri dalam memulai suatu usaha dalam rangka mencapai profit serta mengembangkan seluruh potensi ekonomi yang dimiliki. Menurut Basrowi dalam Ane Kurniawati (2018:40) JiwaKewirausahaan adalah seorang pebisnisyang muncul sebagai ancaman, pesaingyang agresif, sebaliknya pada pebisnis lainsesama entrepreneur mungkin sebagaisekutu/mitra, sebuah sumber penawaran,seorang pelanggan, atau seorang yangmenciptakan kekayaan bagi orang lain,juga menemukan jalan yang lebih baikuntuk memanfaatkan sumber-sumber daya,mengurangi pemborosan, danmenghasilkan lapangan pekerjaan barubagi orang lain yang dengan senang hatiuntuk menjalankannya.

Menurut hasil penelitian Suryana (2017:22) ada lima indikator dalam jiwa kewirausahaan, yaitu: 1. Penuh Percaya Diri Penuh keyakinan, optimis, berkomitmen, disiplin, bertanggung jawab merupakan suatu paduan sikap dan keyakinan seseorang dalam menghadapi tugas atau pekerjaan. 2. Memiliki Inisiatif Penuh Energi, cekatan dalam bertindak dan aktif. Artinya selalu ingin mencari dan memulai, untuk memulai diperlukan niat dan tekad yang kuat. 3. Motif berprestasi Orientasi pada hasil dan wawasan ke depan. Orientasi pada hasil artinya orang yang selalu mengutamakan nilai-nilai motif berprestasi, berorientasi pada keberhasilan, ketekunan dan ketabahan. 4. Memiliki jiwa kepemimpin Berani tampil beda, dapat dipercaya dan Tangguh dalam bertindak. 5. Berani mengambil resiko Mengambil resiko dengan penuh perhitungan.

\section{Manajemen Pemasaran}

Manajemen pemasaran pada dasarnya adalah suatu aktivitas pembentukan dan penerapan terhadap suatu strategi perusahaan. Pada saat membuat strategi sangat diperlukan skill untuk 
dapat menyusun strategi dan program perencanaan yang tepat. Fungsi manajemen pemasaran antara lain adalah mempersiapkan produk yang lebih unggul dan inovatif juga membaca pangsa pasar yang sesuai dengan produk yang akan kita pasarkan serta mempromosikan produk baru tersebut pada calon pembeli. Definisi manajemen pemasaran menurut Kotler dan Armstrong (2010:57) pemasaran adalah analisis, perencanaan, implementasi, dan pengendalian dari program-program yang dirancang untuk menciptakan, membangun, dan memelihara pertukaran yang menguntungkan dengan pembeli sasaran untuk mencapai tujuan perusahaan.

Sedangakan manajemen adalah proses perencanaan (Planning), pengorganisasian (organizing) penggerakan (Actuating) dan pengawasan. Sedangkan dalam buku Assauri (2013:12) manajemen pemasaran adalah suatu kegiatan atau aktivitas pemahaman, persiapan, pelaksanaan, dan penerapan suatu rencana atau strategi yang dilaksanakan untuk menciptakan, menyusun, dan mendapatkan keuntungan dari pertukaran dengan tujuan pasar untuk meraih misi di perusahaan dalam jangka waktu yang panjang. Fungsi marketing di dalam perusahaan atau organisasi begitu penting untuk meraih keberhasilan atau kesuksesan dalam perusahaan tersebut. Cutlip et al. dalam Rosy (2020:111) menjelaskan bahwa public relations fungsi manajemen yang membangun dan mempertahankan hubungan yang baik dan bermanfaat antara organisasi dengan publik yang mempengaruhi kesuksesan atau kegagalan organisasi itu.

Kesuksesan dalam setiap perusahaan ketika mempromosikan suatu produk tidak lepas dari perencanan strategi pemasaran yang benar-benar matang serta menggabungkan elemen-elemen yang ada di bauran pemasaran (marketing mix). Strategi marketing begitu penting untuk perusahaan dimana strategi marketing adalah tekhnik dalam meraih misi perusahaan. Menurut Kotler \& Amstrong (2014:72), strategi pemasaran merupakan logika pemasaran yang dapat digunakan oleh perusahaan dengan harapan agar unit bisnis dapat meraih misi perusahaan. Strategi marketing terfokus pada penciptaaan nilai tambah terhadap para pelanggan dan membina komunikasi dengan pelanggan serta mengetahui kebutuhan pasar yakni keinginan pelanggan, riset pelanggan dan pasar, membenahi informasi pemasaran dan data pelanggan, membuat metode pemasaran yang terprogram.

Berikut ini proses penyusunan strategi marketing menurut Kotler \& Amstrong (2014:73-75) adalah sebagai berikut: pertama, Segmentasi Pasar (Market Segmentation), merupakan perilaku mengelompokkan pasar menjadi kelompok pembeli berbeda sesuai kebutuhan, karakteristik, atau kegiatan berbeda yang mungkin membutuhkan produk atau bauran pemasaran terpisah. Kedua, Pembentukan Target Pasar (Market Targeting), merupakan proses mengevaluasi daya tarik masing-masing pangsa pasar dan memilih satu atau lebih pangsa pasar yang akan dipenuhi, penetapan sasaran pasar terdiri dari mendesign strategi untuk membangun hubungan komunikasi yang efektif dengan pelanggan yang tepat, atau suatu perusahaan besar dapat memutuskan untuk memberikan suatu penawaran ragam produk yang lengkap dalam melayani seluruh pangsa pasarnya, sebagian besar perusahaan memasuki pasar baru dengan melayani segmen tunggal, dan apabila hal ini terbukti berhasil, mereka menambahkan segmen pasar yang sesuai dengan kebutuhan pasar. Tiga, Diferensiasi dan Posisi Pasar (Differentiation \& Positioning), dalam perusahaan harus memutuskan bagaimana mendiferensiasikan penawaran pasarnya untuk setiap segmen pasar, sasaran produk dan posisi apa yang ingin ditempatinya dalam segmen tersebut, posisi produk merupakan suatu wadah yang diduduki oleh produk relatif menarik dan banyak terhadap pesaingnya dalam pikiran konsumen, pemasar ingin mengembangkan posisi pasar unik bagi produk mereka.

Setelah strategi pemasaran dibuat maka dari itu perusahaan diharapkan untuk dapat menerapkan dan merencanakan rincian dari bauran pemasaran (Marketing Mix). Menurut Kotler \& 
Amstrong (2014:76), bauran pemasaran terdiri dari semua hal yang dapat dilakukan oleh perusahaan untuk dapat mempengaruhi permintaan akan produknya dan terdiri dari "empat P" yakni: pertama, Produk (product), merupakan atau terdiri dari barang dan jasa yang ditawarkan oleh suatu perusahaan kepada target pasar, sasarannya meliputi: ragam, kualitas, desain. fitur, nama merek, dan kemasan. Kedua, Harga (price), merupakan nilai uang yang harus dibayarkan pelanggan untuk dapat memperoleh produk meliputi: daftar harga, diskon potongan harga, periode pembayaran, dan persyaratan kredit. Ketiga, Tempat (place), yaitu aktivitas perusahaan yang membuat produk tersedia untuk kebutuhan pelanggan sasaran meliputi: Lokasi, saluran distribusi, persediaan, transportasi dan logistik. Keempat, Promosi (promotion) berarti kegiatan yang menginformasikan manfaat dari produk dan membujuk pelanggan agar membelinya meliputi: Iklan dan promosi penjualan. Aktivitas promosi merupakan salah satu bagian dari bauran pemasaran perusahaan, yang isinya memberikan informasi kepada masyarakat atau konsumen tentang produk atau jasa yang ditawarkan perusahaan. Kegiatan promosi merupakan kegiatan komunikasi antara perusahaan dengan pelanggan atau konsumen. Sedangkan dalam perusahaan sendiri marketing merupakan department yang bertanggung jawab terhadap strategi pemasaran dan pencapaian target penjualan. (Rosy, 2020:113)

\section{Keberhasilan Usaha}

Untuk menjaga usia perusahaan hidup lebih lama dan mencapai sebuah keberhasilan dalam mengelola sebuah usaha tentunya harus ada strategi yang digunakan terutama dalam menghadapi persaingan yang ada. Setiap wirausaha tentunya menginginkan harapan usia perusahaannya yang panjang, pencapaian keberhasilan dan kelancaran dalam mengelola usaha sehingga orientasi pada hasil bisa tercapai dengan maksimal. Moch. Kohar mudzakar dalam buku Ressa Andari (2011:21) mengatakan bahwa keberhasilan usaha merupakan suatu keadaan yang menggambarkan lebih dari pada yang lainya yang sederajat/ sekelasnya.

Keberhasilan suatu usaha menurut Suryana (2011:85) merupakan keberhasilan dari usaha dalam meraih tujuan. Merujuk pada pendapat tersebut, bisa disimpulkan bahwa suatu usaha dikatakan berhasil jika mempunyai satu kelebihan dibandingkan dengan pada sebelumnya atau dengan perusahaan setara.

\section{METODE PENELITIAN}

Tipe penelitian yang digunakan dalam penelitian ini adalah eksplanasi (Explanatory Research), penelitian ini mencari hubungan dan pengaruh dari dua variabel, yaitu antara variabel jiwa wirausaha dan variabel manajemen usaha dengan variabel keberhasilan usaha. Menurut Sugiyono (2017:6), explanatory research merupakan metode penelitian yang bermaksud menjelaskan kedudukan variabel-variabel yang diteliti serta pengaruh antara variabel satu dengan variabel lainnya. Sedangkan menurut Mulyadi (2012:73) Penelitian Eksplanasi Objek telaahan penelitian eksplanasi (explanatory research) adalah untuk menguji hubungan atau pengaruh antar-variabel yang dihipotesiskan. Pada jenis penelitian ini, tentu ada hipotesis yang akan diuji kebenarannya. Hipotesis yang menunjukkan adanya hubungan antar konsep; hipotesis itu sendiri menggambarkan hubungan antara dua atau lebih variabel; untuk mengetahui apakah sesuatu variabel berasosiasi ataukah tidak dengan variabel lainnya; atau apakah sesuatu variabel disebabkan/dipengaruhi ataukah tidak oleh variabel lainnya.

Pendekatan yang digunakan peneltian ini adalah pendekatan kuantitatif yaitu dikatakan metode kuantitatif karena data penelitian berupa angka-angka dan analisis menggunakan statistik. Skala 
pengukuran yang digunakan yaitu skala likert. Skala yang digunakan dalam desain pengukuran penelitian ini adalah skala Likert. Menurut (Sugiyono, 2014:132) Skala Likert digunakan untuk mengukur sikap, pendapat, dan persepsi seseorang atau sekelompok orang tentang fenomena sosial.

Menurut Sugiyono (2017: 35), metode kuantitatif diartikan sebagai metode penelitian yang berlandaskan pada filsafat positivisme, digunakan untuk meneliti populasi atau sample tertentu. Pemilihan populasi dari penelitian ini adalah kelompok usaha kecil dan menengah yang berada dilingkungan agrowisata Lembah Bambu Kuning, dimana usaha tersebut masuk ke dalam ruang lingkup wilayah geografis Kabupaten Lampung Utara. Jenis data penelitian ini adalah data kualitatif dan data kuantitatif.

Sumber data primer dan dan data sekunder. Dalam penggunaan data primer, pengambilan data yang terhimpun langsung oleh peneliti dengan cara melakukan wawancara dan observasi di lapangan. Data primer dapat melalui wawancara dan observasi. Data sekunder adalah data yang didasarkan atas laporan atau publikasi yang berdasarkan penelitian sebelumnya atau dari laporan-laporan lembaga yang menerbitkan informasi atau data yang dibutuhkan. Data sekunder juga didapat dari beberapa sumber, yaitu studi kepustakaan dan internet. (Rosy, 2017:256)

Tekhnik pengumpulan datanya menggunakan tekhnik kuisioner, wawancara, dan dokumentasi. Tekhnik pengolahan datanya adalah tahap editing, coding, dan tabulating. Uji validitas memakai rumus product moment dan uji reabilitasnya memakai rumus Alpha Corn Bach, sedangkan alat analisisnya adalah regresi berganda.

Menurut Sugiyono dalam Kusnadi (2016:91) Hipotesis adalah suatu jawaban sementara atau hasil dari penelitian sementara yang mengacu pada rumusan masalah penelitian, dimana rumusan masalah peneliti sudah dibuat dalam bentuk kalimat pertanyaan. Dikatakan sementara oleh banyaknya peneliti, karena jawaban yang diberikan baru berdasarkan pada teori yang relevan, belum berdasarkan pada fakta-fakta empiris atau kenyataan dari hasil penelitian yang diperoleh melalui pengumpulan data. Jadi hipotesis pun bisa dikatakan sebagai jawaban teoritis terhadap rumusan masalah penelitian, belum bisa dikatakan sebagai jawaban yang emperik. Untuk mendapatkan koefisien regresi yang BLUE, maka dari itu perlu dilakukan pemeriksaan asumsi- asumsi untuk dapat mendapatkan hasil yang lebih akurat. Perhitungan dilakukan dengan bantuan software SPSS.

Hipotesis:

H1: Ada pengaruh positip antara jiwa wirausahadan manajemen pemasaran secara parsial terhadap keberhasilan usaha para pelaku Usaha Mikro Kecil dan Menengah (UMKM)di Agrowisata Lembah Bambu Kuning Desa Abung Jaya Kecamatan Abung Selatan Kabupaten Lampung Utara?

H2: Ada pengaruh positip antara jiwa wirausahadan manajemen pemasaran secara simultan terhadap keberhasilan usaha para pelaku Usaha Mikro Kecil dan Menengah (UMKM) di Agrowisata Lembah Bambu Kuning Desa Abung Jaya Kecamatan Abung Selatan Kabupaten Lampung Utara?

\section{HASIL PENELITIAN DAN PEMBAHASAN}

\section{Uji Validitas}


Menurut Sugiyono dalam Ratika Zahra (2014:24) validitas menunjukan derajat ketepatan antara data yang sesungguhnya terjadi pada obyek dengan data yang dapat dikumpulkan oleh peneliti. Hasil dari uji validitas dan reliabilitas menyatakan bahwa semua item pertanyaan yang dipakai pada penelitian ini adalah valid dan reliabel. Agar dapat mengetahui apakah koefisien regresi merupakan koefisien yang BLUE atau tidak, maka dari itu haruslah dilakukan pemeriksaan terhadap asumsi-asumsinya sebagai berikut:

\section{Pengujian Prasyarat Analisis}

\section{Uji Normalitas}

Beberapa metode uji normalitas yaitu dengan melihat penyebaran data pada sumber diagonal pada grafik Normal P-P Plot of regression standardized residual (metode grafik) atau dengan uji OneSample Kolmogorov Smirnov (Imam Ghozali, 2011:173). Untuk memeriksa kenormalan, dalam penelitian ini menggunakan uji Kolmogorov Smirnov. Hasil output SPSS diperoleh:

Tabel 2. Uji Kolmogorov-Smirnov Test One-Sample Kolmogorov-Smirnov Test

\begin{tabular}{|c|c|c|c|}
\hline & & & $\begin{array}{c}\text { Unstandardized } \\
\text { Residual } \\
\end{array}$ \\
\hline $\mathrm{N}$ & & & 30 \\
\hline \multirow[t]{2}{*}{ Normal Parameters ${ }^{a, b}$} & Mean & & ,0000000 \\
\hline & Std. Deviation & & 2,72679682 \\
\hline \multirow[t]{3}{*}{ Most Extreme Differences } & Absolute & & , 139 \\
\hline & Positive & &, 069 \\
\hline & Negative & &,- 139 \\
\hline Test Statistic & & & ,139 \\
\hline Asymp. Sig. (2-tailed)c & & & 146 \\
\hline \multirow[t]{3}{*}{ Monte Carlo Sig. (2-tailed)d } & Sig. & & 145 \\
\hline & $99 \%$ Confidence Interval & Lower Bound & 136 \\
\hline & & Upper Bound & 154 \\
\hline
\end{tabular}
a. Test distribution is Normal.
b. Calculated from data.
c. Lilliefors Significance Correction.
d. Lilliefors' method based on 10000 Monte Carlo samples with starting seed 2000000.

Melihat tabel diatas, terlihat bahwa nilai Asymp. Sig sebesar 0,146 dengan menggunakan taraf signifikansi $(\alpha)$ sebesar 0,05, ternyata nilai Asymp. Sig $>0,05$, sehingga residual berdistribusi normal.

\section{Uji Multikolinearitas}

Uji multikolinieritas bertujuan untuk menguji apakah model regresi ditemukan adanya korelasi antar variabel bebas (independen). Model regresi yang baik seharusnya tidak terjadi korelasi diantara variabel independen. Jika variabel independen saling berkolerasi, maka variabelvariabel ini tidak ortogonal. Variabel orthogonal adalah variabel independen yang nilai korelasi antar sesama variabel independen sama dengan nol (Imam Ghozali, 2011:105). 
Untuk mengetahui ada tidaknya masalah multikolinearitas, maka dari itu digunakan lah metode Marquardt, dengan melihat nilai Variance Inflation Faktor (VIF). Hasil SPSS diperoleh sebagai berikut:

Tabel 3. Uji Multikolinearitas

\begin{tabular}{|c|c|c|c|c|c|c|c|c|}
\hline \multicolumn{9}{|c|}{ Coefficients $^{a}$} \\
\hline \multirow{2}{*}{\multicolumn{2}{|c|}{ Model }} & \multicolumn{2}{|c|}{ Unstandardized Coefficients } & \multirow{2}{*}{$\begin{array}{c}\text { Standardized } \\
\text { Coefficients } \\
\text { Beta } \\
\end{array}$} & \multirow[t]{2}{*}{$\mathrm{t}$} & \multirow[t]{2}{*}{ Sig. } & \multicolumn{2}{|c|}{ Collinearity Statistics } \\
\hline & & B & Std. Error & & & & Tolerance & VIF \\
\hline 1 & (Constant) & 14,533 & 7,179 & & 2,024 & ,053 & & \\
\hline & JIWA WIRAUSAHA & ,151 & ,146 & ,188 & 1,034 & ,311 & ,993 & 1,007 \\
\hline & MANAJEMEN PEMASARAN & ,205 & 147 & 254 & 1,395 & ,174 & ,993 & 1,007 \\
\hline
\end{tabular}

a. Dependent Variable: KEBERHASILAN USAHA

Dengan berdasarkan Tabel diatas dapat kita diketahui bahwa nilai VIF masing-masing variabel bebas terhadap variabel bebas yang lain lebih kecil dari 10, hal ini berarti menunjukkan tidak ada gejala multikolinearitas pada masing-masing variabel bebas.

Dasar pengambilan keputusan Uji Multikolinieritas Tolerance dan VIF adalah sebagai berikut: Menurut Imam Ghozali tidak terjadi gejala Multikolinieritas, jikanilai tolerance > 0,100 dan nilai VIF $<10,00$

Nilai Tolerance $0,993>0,100$

VIF $1,007<10,00$

Kesimpulannya adalah tidak ada gejala Multikolinieritas.

a. Uji Heteroskedastisitas

Untuk dapat mengetahui ada atau tidaknya masalah heteroskedastisitas perlu dilakukan pengujian dengan tekhnik uji Glejser. Tidak terjadi heteroskedastisitas, jika tidak ada pola yang jelas (bergelombang melebar kemudian menyempit) pada gambar scatterplots, serta titik-titik menyebar diatas dan dibawah angka 0 pada sumbu Y (Imam Ghozali, 2011:139). Berdasarkan hasil output SPSS adalah sebagai berikut:

\section{Gambar 1. Uji Heterokedastisitas}




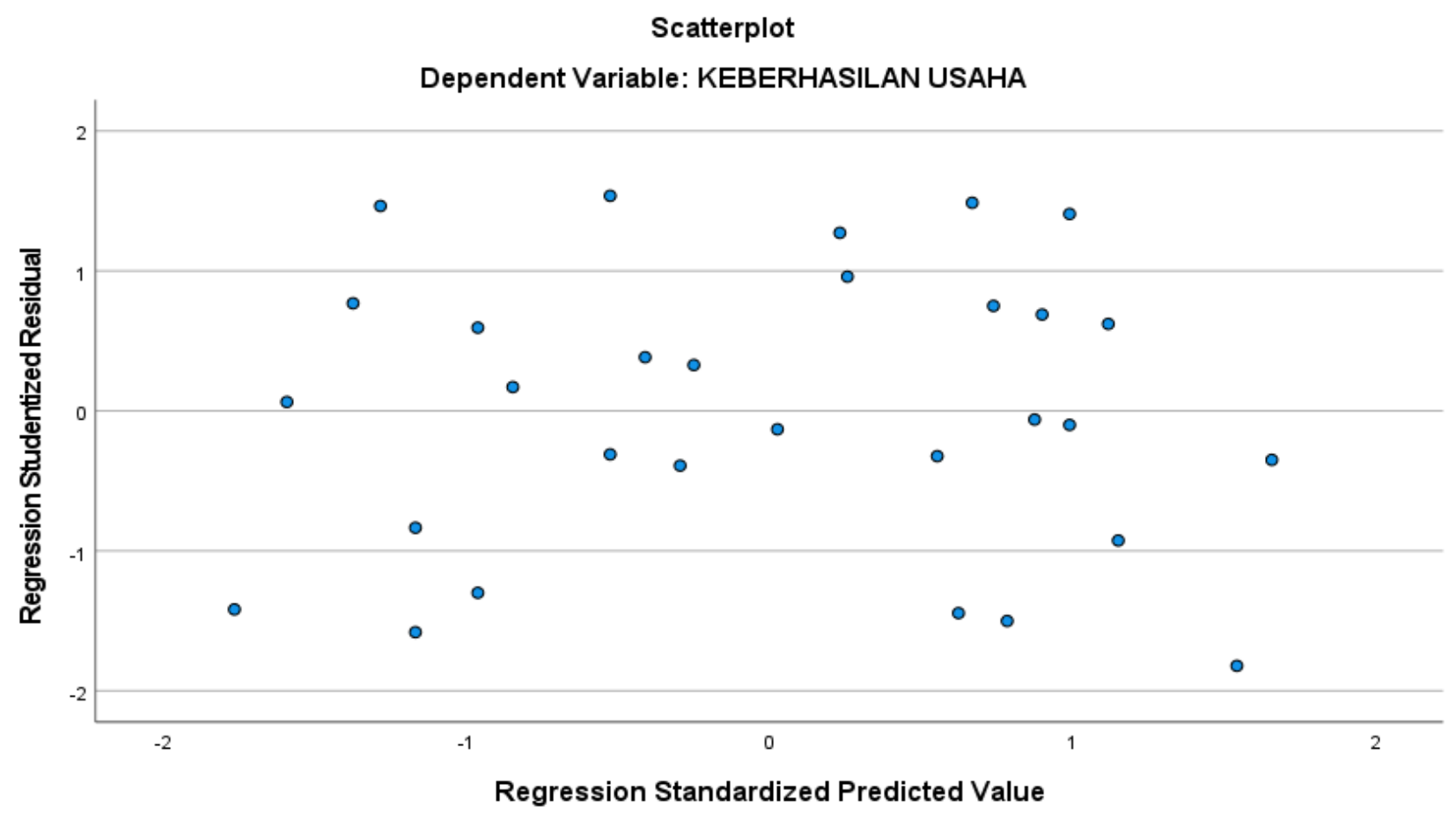

Dasar pengambilan keputusan uji heteroskedastisitas adalah scatterplot dan kesimpulan bahwa tidak ada gejala heteroskedastisitas.

\section{Uji Autokorelasi}

Untuk dapat memeriksa ada atau tidaknya autokorelasi, dalam penelitian ini menggunakan tekhnik uji Darwin-Watson. Menurut Rosalendro (2016:187) salah satu cara yang umum digunakan untuk mendeteksi adanya autokorelasi dalam regresi linear berganda adalah dengan Uji Durbin Watson (DW). Uji D-W merupakan salah satu uji yang banyak dipakai untuk mengetahui ada tidaknya autokorelasi.

Melihat data dari output SPSS diperoleh nilai Durbin Watson (DW) sebesar 1,142. Dengan taraf signifikansi $(\alpha)$ sebesar 0,05; maka dari itu diperoleh nilai $\mathrm{DL}=1,2837$ dan $\mathrm{DU}=1,5666$. Ternyata nilai DW $=2,7163$ terletak diantara DU dan 2 (DU < DW < 2), sehingga dapat dikatakan tidak ada autokorelasi. Jadi asumsi tidak ada autokorelasi yang terpenuhi.

\section{Tabel 4. Uji Autokorelasi}

\begin{tabular}{ll|r|r|r|r} 
& \multicolumn{5}{c}{ Model Summary $^{\mathbf{b}}$} \\
Model & $\mathrm{R}$ & $\mathrm{R}$ & $\begin{array}{c}\text { Adjusted R } \\
\text { Square }\end{array}$ & $\begin{array}{c}\text { Std. Error of the } \\
\text { Estimate }\end{array}$ & Durbin-Watson \\
\hline 1 &, $329^{\mathrm{a}}$ &, 108 &, 042 & 2,796 & 1,142 \\
\hline
\end{tabular}

a. Predictors: (Constant), MANAJEMEN PEMASARAN, JIWA WIRAUSAHA

b. Dependent Variable: KEBERHASILAN USAHA

Dalam bukunya Singgih Santoso (2012:242) pada pengambilan keputusan ada atau tidaknya autokorelasi dengan menggunakan Durbin Watson Test (D-W Test) adalah sebagai berikut:

a. Bila nilai D-W terletak dibawah -2 berarti diindikasikan ada autokorelasi positif.

b. Bila nilai D-W terletak diantara -2 sampai +2 berarti di indikasikan tidak ada autokorelasi.

Bila nilai D-W diatas +2 berarti di indikasikan ada autokorelasi negatif. 


$$
\begin{array}{ll}
\mathrm{X}_{1} & =\text { Jiwa Wirausaha } \\
\mathrm{X}_{2} & =\text { Manajemen Pemasaran } \\
\mathrm{Y} & =\text { Keberhasilan Usaha } \\
\mathrm{N} & =30
\end{array}
$$

\begin{tabular}{|c|c|c|c|c|}
\hline $\mathbf{d}$ & $\mathbf{d l}$ & $\mathbf{d u}$ & 4-dl & 4-du \\
\hline 1,142 & 1,2837 & 1,5666 & 2,7163 & 2,4334 \\
\hline
\end{tabular}

Karena $\quad=\mathrm{du}<\mathrm{d}<4$-du

$$
=1,5666<1,142<2,4334
$$

Kesimpulan $=$ Tidak Terdapat Autokorelasi

\section{BAHASAN}

\section{Uji Regresi Linear Berganda}

Analisis regresi linier berganda digunakan untuk meramalkan bagaimana keadaan (naik turunnya) variabel dependen, bila dua arah atau lebih variabel independen sebagai faktor prediktor dimanipulasi (dinaik turunkan nilainya) jadi analisis regresi ganda akan dilakukan bila jumlah variabel independennya minimal 2 (dua) (Sugiyono, 2013:277).

Ada beberapa tekhnik atau metode uji normalitas yaitu dengan cara melihat penyebaran data pada sumber diagonal pada grafik Normal P-P Plot of regression standardized residual (metode grafik) atau dengan uji One Sample Kolmogorov Smirnov (Imam Ghozali, 2011:173).

Dengan berdasarkan perhitungan menggunakan bantuan aplikasi sotware yaitu SPSS dapat dituangkan hasil analisis regresi linier berganda sebagai berikut:

\section{Uji Normalitas Probablity Plot}

Dasar pengambilan keputusan Uji Normalitas Probability Plot menurut Imam Ghozali (2011:161) model regresi dikatakan berdistribusi normal jika data ploting (titik-titik) yang menggambarkan data sesungguhnya mengikuti garis diagonal.

\section{Gambar 2. Uji Normalitas Probability Plot}

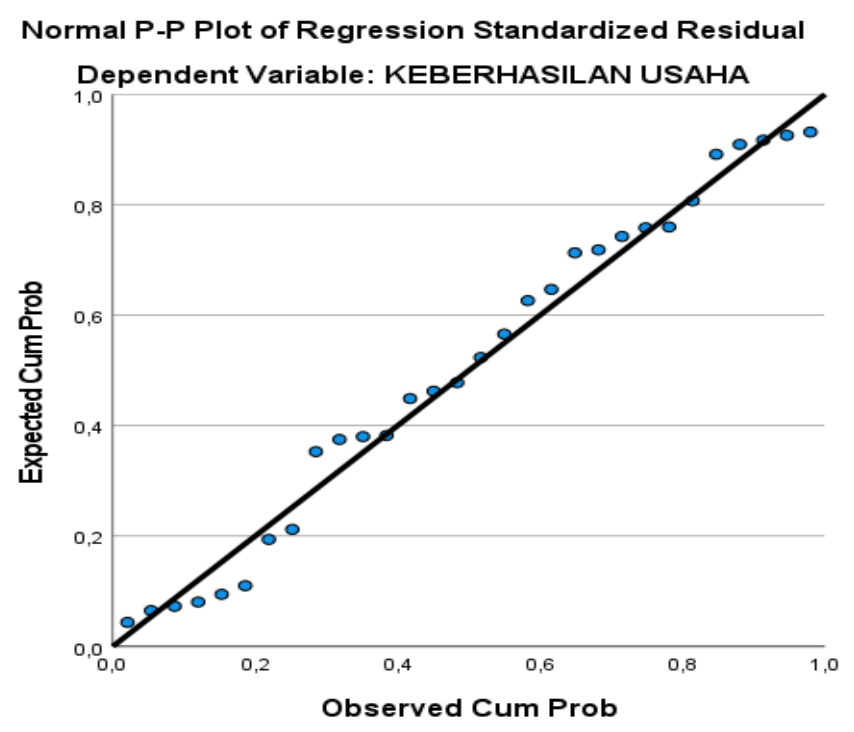


Kesimpulan Uji Normalitas Probability Plot adalah Model Regresi berdistribusi Normal.

\section{Uji Parsial (Uji t)}

Menurut Lind et al. dalam Marita (2015:29) Uji t pada dasarnya dilakukan untuk menguji pengaruh dari masing-masing variabel bebas terhadap variabel terikatnya.Dasar pengambilan keputusan Uji t Parsial (Regresi Linear Berganda) berdasarkan nilai signifikansi. Menurut Imam Ghozali (2011:101) jika nilai Sig < 0,05 maka artinya variabel independent (X) secara parsial berpengaruh terhadap variabel dependent (Y).

Tabel 5. Regresi Linear Berganda

\begin{tabular}{|c|c|c|c|c|c|c|c|c|}
\hline & & & Coefficie & & & & & \\
\hline & & Unstandarc & Coefficients & $\begin{array}{l}\text { Standardized } \\
\text { Coefficients }\end{array}$ & & & Collinearity & istics \\
\hline & del & $\mathrm{B}$ & Std. Error & & $\mathrm{t}$ & Sig. & Tolerance & VIF \\
\hline 1 & (Constant) & 14,533 & 7,179 & & 2,024 &, 053 & & \\
\hline & JIWA WIRAUSAHA & 151 &, 146 & , 188 & 1,034 & ,311 & ,993 & 1,007 \\
\hline & MANAJEMEN PEMASARAN & 205 & 147 & 254 & 1,395 & 174 & ,993 & 1,007 \\
\hline
\end{tabular}

a. Dependent Variable: KEBERHASILAN USAHA

Kesimpulan:

1. Nilai Sig Variabel $\left(\mathrm{X}_{1}\right)=0,311>0,05$ artinya Jiwa Wirausaha $\left(\mathrm{X}_{1}\right)$ tidak berpengaruh terhadap keberhasilan usaha (Y)

2. Nilai Sig Variabel $\left(X_{2}\right)=0,174>0,05$ artinya Manajemen Pemasaran $\left(X_{2}\right)$ tidak berpengaruh terhadap keberhasilan usaha $(\mathrm{Y})$

Sedangkan dasar pengambilan keputusan Uji t Parsial (Regresi Linear Berganda) berdasarkan nilai $\mathrm{t}$ hitung dan $\mathrm{t}$ tabel adalah sebagai berikut:

Menurut V.Wiratna Sujarweni (2014:155) jika nilai $\mathrm{t}$ hitung $>\mathrm{t}$ tabel maka artinya variabel independent (X) secara parsial berpengaruh terhadap variabel dependent (Y).

Rumus mencari $\mathrm{t}_{\text {tabel }}=(\alpha / 2 ; \mathrm{n}-\mathrm{k}-1)$

$$
\begin{aligned}
& =(0,05 / 2 ; 30-2-1) \\
& =(0,025 ; 27) \\
& =2,052
\end{aligned}
$$

Kesimpulannya adalah variabel $\mathrm{X}_{1=} 1,034<2,052$ dan variabel $\mathrm{X}_{2}=1,395<2,052$

Jiwa Wirausaha $\left(\mathrm{X}_{1}\right)$ tidak berpengaruh terhadap Keberhasilan Usaha (Y) dan Manajemen Pemasaran $\left(\mathrm{X}_{2}\right)$ tidak berpengaruh terhadap Keberhasilan Usaha $(\mathrm{Y})$.

\section{Uji F Simultan}

Menurut Santoso Slamet dalam Lestari (2019:44) Uji F digunakan untuk menguji tingkat signifikan dari pengaruh variabel independen secara serempak terhadap variabel dependen.Dasar pengambilan keputusan Uji F Simultan (Regresi Linear Berganda) berdasarkan nilai Signifikan adalah sebagai berikut:

Menurut Imam Ghozali (2011:101) jika nilai Sig < 0,05 maka artinya variabel independent (X) secara simultan berpengaruh terhadap variabel dependent $(\mathrm{Y})$. 
Tabel 6. Uji Regresi Linear Berganda

\begin{tabular}{|c|c|c|c|c|c|c|}
\hline \multicolumn{7}{|c|}{ ANOVA $^{a}$} \\
\hline Model & & Sum of Squares & $\mathrm{df}$ & Mean Square & $\mathrm{F}$ & Sig. \\
\hline \multirow[t]{3}{*}{1} & Regression & 25,646 & 2 & 12,823 & 1,641 &, $213^{b}$ \\
\hline & Residual & 211,021 & 27 & 7,816 & & \\
\hline & Total & 236,667 & 29 & & & \\
\hline
\end{tabular}

a. Dependent Variable: KEBERHASILAN USAHA

b. Predictors: (Constant), MANAJEMEN PEMASARAN, JIWA WIRAUSAHA

Uji F Simultan dari variabel independent (X) terhadap variabel dependent (Y) adalah $=$ Nilai Sig $>0,05$

$=0,213>0,05$

Kesimpulan Uji F Simultan adalah Jiwa wirausaha $\left(\mathrm{X}_{1}\right)$, Manajemen Pemasaran $\left(\mathrm{X}_{2}\right)$ secara Simultan tidak berpengaruh terhadap Keberhasilan Usaha (Y).

Sedangkan dasar pengambilan keputusan berdasarkan nilai hitung dan tabel adalah sebagai berikut:

Menurut V. Wiratna Sujarweni (2014:154) jika nilai $F_{\text {hitung }}>F_{\text {tabel }}$ maka artinya variabel independent (X) secara Simultan berpengaruh terhadap variabel dependent (Y).

Rumus mencari $\mathrm{F}_{\text {tabel }}=(\mathrm{k} ; \mathrm{n}-\mathrm{k})$

$$
\begin{aligned}
& =(2 ; 30-2) \\
& =2 ; 28 \\
& =3,32
\end{aligned}
$$

Kesimpulannya adalah nilai $\mathrm{F}_{\text {hitung }}>\mathrm{F}_{\text {tabel }}=1,641<3,32$

Jiwa wirausaha $\left(\mathrm{X}_{1}\right)$ dan Manajemen Pemasaran $\left(\mathrm{X}_{2}\right)$ tidak berpengaruh terhadap Keberhasilan Usaha (Y).

\section{Uji Persentase Secara Parsial dan Simultan}

Persentase pengaruh yang diberikan variabel $(\mathrm{X})$ baik secara parsial maupun secara simultan terhadap variabel $(\mathrm{Y})$ adalah $=0,108 \times 100$

$$
=10,8 \%
$$

\begin{tabular}{|c|c|c|c|c|c|}
\hline \multirow[b]{2}{*}{ Model } & & & 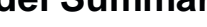 & & \multirow[b]{2}{*}{ Durbin-Watson } \\
\hline & $\mathrm{R}$ & R Square & $\begin{array}{l}\text { Adjusted R } \\
\text { Square }\end{array}$ & $\begin{array}{l}\text { Std. Error of the } \\
\text { Estimate }\end{array}$ & \\
\hline 1 & ,329a & 108 & ,042 & 2,796 & 1,142 \\
\hline
\end{tabular}

\section{Tabel 7. Uji Regresi Linear Berganda Model Summary ${ }^{\mathrm{b}}$}

a. Predictors: (Constant), MANAJEMEN PEMASARAN, JIWA WIRAUSAHA

b. Dependent Variable: KEBERHASILAN USAHA

\section{Uji Hipotesis}

Dengan melihat hasil analisis data yang lolos dari uji asumsi klasik, maka dari itu dapat dilakukan pembahasan penelitian untuk masing-masing hipotesis yang telah dirumuskan sebelumnya yaitu sebagai berikut: Hasil uji t, dengan taraf signifikansi $\alpha=0,05$, semua nilai 
Sig dari koefisien regresi lebih besar dari 0,05 , sehingga dapat menunjukkan pengujian yang terdiri dari jiwa wirausaha dan manajemen pemasaran secara parsial berpengaruh negatif dan signifikan terhadap keberhasilan usaha para pelaku Usaha Mikro Kecil dan Menengah (UMKM) di Agrowisata Lembah Bambu Kuning Desa Abung Jaya Kecamatan Abung Selatan Kabupaten Lampung Utara dengan demikian hipotesis pertama tidak terbukti. Lalu dapat dilihat dari hasil uji F diperoleh nilai sig sebesar 0,000. Dengan taraf signifikansi $\alpha=0,05$, ternyata nilai sig > 0,05, sehingga menunjukkan pengujian yang signifikan. Ini berarti variabel jiwa wirausaha dan manajemen pemasaran secara simultan berpengaruh negatif dan signifikan terhadap keberhasilan usaha para pelaku Usaha Mikro Kecil dan Menengah (UMKM) di Agrowisata Lembah Bambu Kuning Desa Abung Jaya Kecamatan Abung Selatan Kabupaten Lampung Utara dengan demikian hipotesis kedua yang diajukan tidak terbukti

\section{E. SIMPULAN}

Dengan berdasarkan data dari hasil penelitian yang telah dilakukan oleh peneliti maka dari itu diperoleh kesimpulan yakni Signifikasi untuk variabel jiwa kewirausahaan sebesar 0,001 yang lebih besar dari 0,05. Jadi dapat ditarik kesimpulan bahwa Ha ditolak sedangkan Ho ditolak, karena jiwa wirausaha dan manajemen pemasaran berpengaruh negatif terhadap keberhasilan usaha. Pengaruh Jiwa Wirausaha terhadap Keberhasilan Usaha ditunjukan oleh R Square = 0,108 yang artinya bahwa Keberhasilan Usaha dipengaruhi 0,108 atau 10,8\% oleh Jiwa Kewirausahaan dan Manajemen Pemasaran selebihnya dipengaruhi oleh faktor lain diluar perusahaan.

\section{DAFTAR PUSTAKA}

\section{Buku:}

Aufar, Arizali. 2014. Faktor-Faktor yang Mempengaruhi Penggunaan Informasi Akuntansi Pada UMKM (Survei Pada Perusahaan Rekanan PT. PLN (Persero) di Kota Bandung).

Suparyanto, (2012). Kewirausahaan Konsep dan Realita Pada Usaha Kecil. Bandung: Alfabeta Eddy Soeryanto Soegoto. 2014. Entrepreneurship Menjadi Pembisnis Ulung. Elex Media Computindo

Yuyus Suryana dan Kartib Bayu. 2013. Pendekatan Karakteristik Wirausaha Sukses. Penerbit: Prenada Media Group.

Suryana. 2014. Kewirausahaan. Jakarta: Salemba Empat.

Suryana. 2017. Ekonomi Keatif, Ekonomi Baru: Mengubah Ide dan Menciptakan Peluang. Jakarta: Salemba Empat

Philip Kotler \& Garry Armstrong. 2010. Prinsip-Prinsip Pemasaran, Jilid 1 dan 2 Edisi Kedua Belas. Jakarta: Erlangga

Sofjan Assauri. 2013. Manajemen Pemasaran. Jakarta: Rajawali Pers

Philip Kotler dan Amstrong, Gary. 2014. Principles of Marketin, 12th Edition, Jilid 1 Terjemahan Bob Sabran Jakarta: Erlangga

Ressa Andari. 2011. Pengaruh kompetensi pengusaha, skala usaha dan saluran pemasaran terhadap keberhasilan usaha (survey pada industri bawang goreng di kabupaten kuningan). Skripsi UPI Bandung.Tersedia di: repository.upi.edu3.

Suryana. 2011. Kewirausahaan Pendoman Praktis: Kiat dan Proses Menuju Sukses. Jakarta: Salemba Empat

Sugiyono. 2017. Metode Penelitian Kuantitatif, Kualitatif, dan R\&D. Bandung: Alfabeta, CV. Sugiyono. (2014) Metode Penelitian Kuantitatif Kualitatif dan R\&D. Bandung : Alfabeta. 
Ghozali, Imam. 2011. “Aplikasi Analisis Multivariate Dengan Program SPSS”.

Santoso, Singgih. 2012. Panduan Lengkap SPSS Versi 20. Jakarta: PT Elex Media Komputindo.

Sugiyono, 2013, Metodelogi Penelitian Kuantitatif, Kualitatif Dan R\&D. (Bandung: ALFABETA)

Sujarweni, V. Wiratna. 2014. Metode Penelitian: Lengkap, Praktis, dan Mudah Dipahami. Yogyakarta: Pustaka Baru Press.

\section{Jurnal:}

Daud, Rosy. "Kampanye Public Relations Partai Nasional Demokrat (Nasdem) Melalui Sosialisasi Program Kampung Enterpreneur Creative (Kece) Untuk Meningkatkan Kesejahteraan Ekonomi (Studi Pada Calon Gubernur Lampung Mustafa).” Prosiding Seminar Nasional FISIP Universitas Lampung (SEFILA) II, http://repository.lppm.unila.ac.id/11146/

Daud, Rosy, Khairunnisa. "Peran Marketing Public Relations (MPR) Dalam Membangun Brand Image Warunk Upnormal Di bandung." Jurnal Komunikasiana Journal Of $\begin{array}{lllll}\text { Communication } & \text { Studies } & 2, & \text { no.2 } & \text { (2020): }\end{array}$ http://dx.doi.org/10.24014/kjcs.v2i2.11331

Kurniawati, Ane. "Pengaruh Jiwa Kewirausahaan dan Kreativitas Terhadap Kinerja Keuangan.” Jurnal Ekonomi Manajemen 4, no.1 (2018): 38-46. https://doi.org/10.37058/jem.v4i1

Mulyadi, Mohammad. "Riset Desain Dalam Metodologi Penelitian.’Jurnal Studi Komunikasi Dan Media16, no.1 (2012): 71-80. http://dx.doi.org/10.31445/jskm.2012.160106

Zahra, Ratika, Nofha Rina. "Pengaruh Celebrity Endorser Hamidah Rachmayanti Terhadap Keputusan Pembelian Produk Online Shop Mayoutfit Di Kota Bandung." Jurnal Lontar 6, no.1 (2018): 43-57. https://doi.org/10.30656/lontar.v6i1.648

Nugroho, Rosalendro Eddy. “Analisis Faktor - Faktor Yang Mempengaruhi Pengangguran Di Indonesia Periode 1998 - 2014.” Jurnal PASTI (Jurnal Penelitian dan Aplikasi Sistem $\begin{array}{llllll}\text { dan Tekhnik } \quad \text { Industri) } & \text { 10, no.2 } & \text { (2016): }\end{array}$ https://publikasi.mercubuana.ac.id/index.php/pasti/article/view/1587/1223

Marita, Widya Exsa. "Pengaruh Struktur Organisasi Dan Ukuran Perusahaan Terhadap Penerapan Business Entity Concept.”Jurnal AKRUAL (Jurnal Akuntansi) 7, no.1 (2015): 18-40. http://dx.doi.org/10.26740/jaj.v7n1.p18-40

Lestari, Jihan Suci, Umi Farida, Siti Chamidah. "Pengaruh Kepemimpinan, Kedisiplinan, Dan Lingkungan Kerjaterhadap Prestasi Kerja Guru.” Jurnal ASSET (Jurnal Manajemen dan Bisnis) 2, no.2 (2019): 38-55. http://dx.doi.org/10.24269/asset.v2i2.2388

Kusnadi, Yahdi, Mutoharoh. "Pengaruh Keterimaan Aplikasi Pendaftaran Online Terhadap Jumlah Pendaftar Di Sekolah Dasar Negeri Jakarta.” Jurnal PARADIGMA (Jurnal $\begin{array}{llllll}\text { Komputer dan } \quad \text { Informatika) } 18, \quad \text { no.2 } & \text { (2016): }\end{array}$ http://dx.doi.org/10.31294/p.v18i2.1183

Suarmawan, Kadek Agus. "Analisis Faktor-Faktor Yang Mempengaruhi Keberhasilan Usaha Mikro Dan Kecil (Studi Pada Usaha Kerajinan Ingka Di Desa Bulian, Kec. Kubutambahan).” Jurnal Jurusan Pendidikan Ekonomi (JJPE)5, no.1 (2015): 1-10. https://ejournal.undiksha.ac.id/index.php/JJPE/article/viewFile/6377/4420 